\title{
The Effect of Implementation Electronic Performance Management (MKE) on Employee Achievement of PT. Indonesia Port I Belawan Branch
}

\author{
Asri Sanusi $^{1 *}$, Fahmi Sulaiman ${ }^{2}$, Andrysyah $^{3}$, Asmaul Husna ${ }^{4}$, Sheilla Arnila Rianda ${ }^{5}$ \\ \{ asrisanusi.lp3i@gmail.com* ${ }^{*}$ \\ 1,2,3,4,5 Program Studi Adminsitrasi Bisnis, Politeknik LP3I Medan
}

\begin{abstract}
Abstrak: Electronic Performance Management is a digital-based employee performance appraisal system. MKE contains all work plans, targets for each work unit, guidance, training, and employee performance evaluation every month. And at the end of the month, the supervisor must evaluate the results of their employee's work report. The system has also made employee salaries different from each other because they are measured by performance and target achievement. Employee achievement is a condition where the work of quality and quantity is achieved by an employee in carrying out his duties in accordance with the responsibilities given to him. The type of data used in this study is primary data and the data sources used are internal data. The population and samples studied were employees of PT Indonesia Port I Belawan Branch of Unloading Business Division (UBM), which amounted to 24 people with engineering and tool operators. Methods of data collection in the form of questionnaires and observations. The results of the coefficient of determination analysis show that the independent variable (electronic performance management) is able to explain the dependent variable (employee performance) of $64 \%$ and $36 \%$ influenced by other factors. The results of the test show that the hypothesis $\mathrm{HO}$ is rejected and $\mathrm{Ha}$ is accepted which means that electronic performance management has a partial effect on employee performance with a value of $6.257 \geq 2.074$. The result of a simple regression analysis of this study is that there is a positive influence between electronic performance management and employee achievement.
\end{abstract}

Keywords: Electronic Performance Management, Employee Achievement

\section{Introduction}

Having skilled, professional and high-achieving resources is a dream for every company. In various companies, they assume that their assets are human resources that must be maintained. to be able to survive and compete in the current era of globalization is quality and productivity that are really very decisive. Seeing the importance of the role of human resources, the company needs to make policies to stimulate employee work performance by providing a work management system that will facilitate managing human resources to be more developed and well-valued performance. One example is PT. Belawan Port Indonesia I Branch which created an Electronic Performance Management (MKE) application. MKE is a digital-based employee performance appraisal system. with this system, all employees' work from the highest to the lowest level can be monitored measurably and transparently. Thedora (2017) in his research with the title: "Comparison of Performance Management of Disabled Employees in Small and Medium Enterprises X and Small and Medium Enterprises Y" is a comparison between SMEs that use performance management that is implemented. The result is UKM Y in managing disabled people has a low turnover and a better level of productivity than SMEs X who have not fully implemented performance management. The difference from 
the theory with the research of the author lies in the application of performance management in small businesses while the authors on state-owned companies. Based on the background above, the formulation of the problem raised in this study is how the influence of the application in electronic performance management on employee performance at PT. Belawan Branch Indonesia I Port. This study only discusses the influence of the application of electronic performance management $(\mathrm{X})$, namely KPI, PKM, RKB, and competencies measured against work performance (Y), namely quality of work, resilience, quality of work, and attitude. to employees of PT. Indonesian Port I Belawan Branch Division of Unloading Business (UBM), which amounted to 24 people. Based on the background and formulation of the problem above, this study aims to determine the effect of the application of electronic performance management on employee performance at PT. Indonesian Port I Belawan Branch Load Unloading Business Division (UBM). This research can add knowledge to the author and an understanding of electronic performance management and its application to human resource management where it has been studied in college and the real world of work.

\section{Theoretical Basis}

There are several indicators in the performance management measurement system as follows:

\subsection{KPI (Key performance Indicator)}

Key performance indicator is the result of achievement of the target at PT. Pelabuhan Indonesia I (Persero) based on 6 perspectives, namely finance, customers, internal business processes, learning and growth, leadership, products and services.

\subsection{PKM (management work program)}

The management work program requires that all employees at the structural level must receive basic training in audit planning so that the supervisory function can be started from the person in charge of the program.

\subsection{RKB (Monthly Performance Plan)}

Inside the monthly performance planthere is a rkb plan or plan. Rkb plan was made at the beginning of the month which included work plans, weights, and coaching conducted in the middle of the month to superiors and the targets to be achieved according to that year. The following month the employees input realization according to the achievement of the month.

\subsection{Competence}

Competence contains the values we get from the monthly budget. Marketers try to identify groups of workers who have above average interest in certain products and services.

\subsection{Job Performance Measurement}

According to Flippo (Sunyoto: 2016: 199) suggests that one's work performance can be measured through:

\subsection{Work Quality}

In this case it relates to the timeliness, skills and personality in doing work.

\subsection{Quality of work}


Relating to the provision of additional tasks given by superiors to that. For example, working overtime.

\subsection{Toughness}

Here it relates to the attendance rate of holiday time and a schedule of late attendance at work.

\subsection{Attitude}

It is the attitude that exists to employees that shows how far their attitudes and responsibilities towards fellow friends and superiors and how far the level of cooperation in evaluating tasks.

\section{Research Methodology}

\subsection{Operational definitions}

According to Sujarweni (2014: 87) Operational definition is a research variable intended to understand the meaning of each research variable before analysis. Example: The Effect of Electronic Performance Management Implementation on Employee Performance at PT. Belawan Branch Indonesia Port I Division of Loading and Unloading Business.

Table 1. Operational Definitions

\begin{tabular}{ll}
\hline Research Variable & Indicator \\
\hline Indicators that become & 1. KPI \\
measurements of & 2. PKM \\
electronic performance & 3. RKB \\
management & 4. Competence \\
\hline Indicators that become & 1. Work quality \\
measurements in work & 2. toughness \\
performance & 3. Quality of work \\
& 4. attitude \\
\hline
\end{tabular}

\subsection{Population}

Source: processed data (2018)

According to Sujarweni (2014: 65) "states the population is the total number consisting of subjects that have certain characteristics and qualities determined by researchers to be investigated and then drawn conclusions". The population studied is the entire employee of PT. Belawan Branch Indonesia Port I, totaling 24 people.

\subsection{Sample}

According to Sujarweni (2014: 65) "states that the sample is part of a number of characteristics possessed by the population used for research".

The sample used in this study is the entire employee of PT. Indonesian Port I Belawan Branch Division of Unloading Business (UBM), which amounted to 24 people. The method used in this sampling is Saturated Sampling because all members of the population are samples.

\subsection{Data Analysis Methods}


The data analysis method used in this study is a quantitative method. In this study have two variables, namely $\mathrm{X}$ and $\mathrm{Y}$. variable $\mathrm{X}$ is Electronic Performance Management and variable $\mathrm{Y}$ is employee achievement. This quantitative method with statistical analysis that focuses on numeric / numerical methods in describing data that has been obtained through questionnaire data that is shared with employees of PT. Belawan Branch Indonesia Port I Division of Loading and Unloading Business.

\section{Results And Discussion}

\subsection{Description of research results}

The number of questionnaires that the author has distributed to the respondents, amounting to 24 people, has returned to $100 \%$ of the authors. The data obtained by the author is described in the form of the following tables:

Table 2. Characteristics of Respondents by Gender

\begin{tabular}{|c|c|c|c|}
\hline No. & Gender & $\begin{array}{l}\text { Number of } \\
\text { people }\end{array}$ & Percentage $(\%)$ \\
\hline 1 & Man & 24 & 100 \\
\hline 2 & Woman & 0 & 0 \\
\hline total & & 24 & 100 \\
\hline
\end{tabular}

Based on table it can be seen that the sex of the overall respondent is male, as many as 24 people $(100 \%)$. This is because the company is engaged in ship cargo services so that it requires more male-dominated operational personnel.

Table 3. Characteristics of Respondents Based on Age Range

\begin{tabular}{cccc}
\hline No. & Age & Number of people & Percentage (\%) \\
\hline 1 & $20-30$ years old & 10 & 41,7 \\
\hline 2 & $30-40$ years old & 3 & 12,5 \\
\hline 3 & $40-50$ years old & 9 & 37,5 \\
\hline 4 & $50-60$ years old & 2 & 8,3 \\
\hline & Jumlah & 24 & 100 \\
\hline
\end{tabular}

Source: Processed data (2018)

Based on table it can be seen that from 24 respondents the age of employees with the highest number is $20-30$ years, 10 people $(41.7 \%)$, then at the age of $30-40$ years as many as 3 people $(12.5 \%)$, for ages $40-50$ years as many as 9 people $(37.5 \%)$, and at the age of 50-60 years there are 2 people $(8.3 \%)$. These results indicate that companies need employees who are young and have good performance.

Table 4. Characteristics of respondents based on Working Time

\begin{tabular}{cccc}
\hline No. & Work & Number of people & Percentage $(\boldsymbol{\%})$ \\
\hline 1 & $<5$ & 8 & 33.3 \\
\hline 2 & $6-10$ & 6 & 25 \\
\hline 3 & $11-15$ & 1 & 4.2 \\
\hline 4 & $16-20$ & 7 & 29.2 \\
\hline 5 & $20-25$ & 2 & 8.3 \\
\hline 6 & $>25$ & 0 & 0 \\
\hline
\end{tabular}




\begin{tabular}{cc}
\hline Jumlah & 24 \\
\hline & Source: Processed data (2018)
\end{tabular}

Based on table, it can be seen that from 24 respondents who have the largest percentage are respondents with a working period of $<5$ years, namely 8 people $(33.3 \%)$, respondents with a working period of 6-10 years as many as 6 people (25\%), respondents with a period 11 15 years work as many as 1 person $(4.2 \%)$, respondents with a work period of 16-20 years as many as 7 people $(29.2 \%)$ and respondents with a work period of 20-25 years as many as 2 people $(8.3 \%)$. This shows that employees have enough loyalty to the company

Table 5. Characteristics of Respondents by Education

\begin{tabular}{llll}
\hline No. & Penghasilan & Jumlah (Orang) & Persentase (\%) \\
\hline 1 & SD & 0 & 0 \\
\hline 2 & SMP & 0 & 0 \\
\hline 3 & SMA & 10 & 41.7 \\
\hline 4 & D 3 & 2 & 8.3 \\
\hline 5 & S1 & 12 & 50 \\
\hline 6 & S2 & 24 & 100 \\
\hline
\end{tabular}

Based on table, it can be seen that from 24 respondents the level of education with the highest number was S1 graduates, 12 people (50\%), DIII graduates were 2 people $(8.3 \%)$, and high school graduates were 10 people $(41.7 \%)$. This shows that the company views in terms of educational qualifications as well as innovative skills or performance in advancing PT. Indonesian Port I Belawan Branch Load Unloading Business Division (UBM).

\section{Discussion}

This study aims to find out about the influence of the implementation of electronic performance management on the achievements of employees of PT. Belawan Branch Indonesia Port I Division of Loading and Unloading Business. The results of the study make a discussion between the theories used and the results obtained by the author. According to Armstrong (Wibowo: 2016: 08) performance management is a systematic process to improve organizational performance by developing individual and team performance. It is a means to get better results by understanding and managing performance within an agreed framework. In accordance with the limitations of the problem, this study only discusses the effect of applying electronic performance management variables $(\mathrm{X})$ as measured by KPI (key performance indicator) indicators, PKM (management performance programs), RKB (monthly performance plans) and competency values on employee performance variables (Y). Based on performance management theory is to make a framework better. And facilitate monitoring with assessment indicators that have been applied.From the results of the study it can be seen that the value of $\mathrm{R}$ Square on the Determination Coefficient is 0.640. This shows the influence of the independent variable (electronic performance management) of $64 \%$ has an effect on the dependent variable (employee performance) of $36 \%$ is influenced by other factors not examined. The $\mathrm{t}$ test shows that the independent variable (Electronic Performance Management) has a significant effect on employee performance that is equal to 0,000. Based on the Electronic Performance Management coefficient value of 0.740 and a positive sign indicates that Electronic Performance Management has a direct relationship with the Employee Performance variable. This also shows that every increase in Electronic Performance Management, the Employee Performance (Y) variable will increase by 7.587. 


\section{Conclusions}

Based on the results of research and discussion that the author did on the employees of PT. Indonesian Port I Belawan Branch Load Unloading Business Division (UBM) can be concluded as follows:

1. The results of the analysis of the coefficient of determination indicate that the independent variable (electronic performance management) is able to explain the dependent variable (employee performance) by $64 \%$.

2. The t-test results show that the hypothesis $\mathrm{HO}$ is rejected and $\mathrm{Ha}$ is accepted which means that electronic performance management has a partial effect on work performance with a value of $6.257 \geq 2.074$

3. The results of a simple regression analysis of 0.740 indicate that electronic performance management has a positive value and a unidirectional relationship if electronic performance management is increased, the employee performance variable will increase by 7.587 .

\section{References}

[1] Hikmawati, Fenti M.Si. (2017), Metodologi Penelitian, Cetakan Pertama, Depok : PT. Raja Grafindo.

[2] Kasmir, S.E.,M.M. (2016), Manajemen Sumber Daya Manusia, Cetakan Pertama, Jakarta : PT. Raja Grafindo.

[3] Sujarweni, V. Wiratna (2014), Metodologi Penelitian, Cetakan Pertama, Yogyakarta : PT. Pustaka Baru

[4] Sugiyono, (2017), Metode Penelitian Pendidikan Pendekatan Kuantitatif, Kualitatif dan $R \& D$, Cetakan Kedua Belas, Bandung : Alfabeta.

[5] Sugiyono, (2014), Metode Penelitian Pendidikan Pendekatan Kuantitatif,

[6] Kualitatif dan $R \& D$, Cetakan Kedua Puluh, Bandung : Alfabeta.

[7] Sunyoto, Danang S.H.,S.E.,MM (2016), Manajemen Sumber Daya Manusia, Cetakan Kedua, Yogyakarta : CAPS (Center Of Academic Publishing Service)

[8] Wibowo, SE.,M.Phil. (2016), Manajemen Kinerja, Cetakan Kelima, Jakarta : PT. Raja Grafindo Persada

[9] Thedora, Agnes (2017), Perbandingan Manajemen Kinerja Karyawan Difabel pada Usaha Kecil Menengah X dan Usaha Kecil Menengah Y, Jurnal Muara Ilmu Sosial, Humaniora, dan Seni Vol. 1 No. 2, Oktober 2017, 336-345

[10] https://jurnal.unpand.ac.id/index.php/MS/article/view/864/839 Accessed on Tuesday, May $22^{\text {nd }}, 2018$, at 17: 41 WIB

[11] http://jurnal.murnisadar.ac.id/index.php/PBI/article/view/21 Accessed on Monday, May $21^{\text {st }} 2018$, at 15: 51 WIB 